\title{
Barbara TóTH* \\ Collective Redress as New Institution of Civil Procedure Code and Its Applicability to Protect Environment ${ }^{* *}$
}

The class action was an invention of equity, mothered by the practical necessity of providing a procedural device so that mere numbers would not disable large groups of individuals, united in interest, from enforcing their equitable rights nor grant them immunity from their equitable wrongs. ${ }^{1}$

\section{Introduction}

The right to healthy environment is a fundamental right, so in the case of this right we can apply the necessity-proportionality test. The Constitutional Court has interpreted it in its decision 18/1994 (20.V), which interpretation is still applicable. In its disposition the Constitutional Court stated that right to healthy environment includes the state is obliged not to decrease the level of environmental protection provided by law. The Fundamental Law contains that anyone who causes damage to the environment shall be obliged to restore it, as an incorporation of the polluter pays principle. This principle could be related to Article P) of Fundamental Law of Hungary, where legislator was drawn up the mandatory liability of protection of environment. The above mentioned decision of Constitutional Court pointed out the obligation of restoration of damage caused to environment arise also from the rules of protection of property. This right is protected by the state by ensuring many measures, like setting up environmental laws or the institution of Vice Commissioner for Fundamental Rights for the Protection of Future Generation. ${ }^{2}$

It is typical in the case of damages caused to environment, that individual claims are (relatively) limited, small, but on the whole are very significant. In the case of low value claims, when the benefits expected from litigation are not exceeding the attached disadvantages and costs, it is not sure that litigation means a beneficial solution, ${ }^{3}$ so if the aggrieved parties should be claim one by one that probably would reduce the effectiveness of litigations. By the way of collective redress plaintiff do not

\footnotetext{
* dr. jur., university assistant, University of Miskolc, Faculty of Law, Private Procedural Law, e-mail: toth.barbara90@gmail.com

** This study has been written as part of the Ministry of Justice programme aiming to raise the standard of law education.

${ }^{1}$ Montgomery Ward \& Co. v.Langer, 168 F. 2d 182, 187 (8th Cir. 1948).

2 Kommentár Magyarország Alaptörvényéhez, XXI. cikk, Wolters-Kluwer, in: https://uj.jogtar.hu/\#doc/db/1/id/A1100425.ATV/ (10.10.2017).

${ }^{3}$ Bencsik Klaudia: A class action eredete és kialakulása a polgári perjogi kodifikáció tükrében, in: http://epa.oszk.hu/02600/02687/00006/pdf/EPA02687_jogi_tanulmanyok_2014_654-

663.pdf (15.11.2017) 2014, 655. and Mariolina Eliantonio: Collective Redress in Environmental Matters in the EU: A Role Model or a 'Problem Child'?, Legal Issues of Economic Integration, 2014/3, 257-259.
} 
have to give up legal representation, thus increasing the chance of initiating the procedure, furthermore it might have positive impact on the defendant's future behaviour by determent from violations of law in the future. Beside the parties, it is beneficial to jurisdiction too: e.g. the workload and cost of administration of courts are decreasing; judicial precedents will be more uniform, etc. ${ }^{4}$

The introduction of collective redress in the Hungarian legal system is not a new idea, but this objective of increasingly importance in other European countries could be reached by constituting the new civil procedure code. ${ }^{5}$ This paper describes the archetypes of collective redress, namely the opt-in and opt-out systems first, after the new procedural rules come into force on the $1^{\text {st }}$ of January, 2018, last but not least those environmental claims where collective redress would be applicable.

\section{The (arche)types of collective redress - the introduction of opt-out and opt-in systems}

We shall have a look at the existing systems because it is true that all models of collective redress based on the American class action, ${ }^{6}$ but this type of system does not exist in its pure form in any European country, and we could find different hybrid permutations around the Continent. That is why we cannot talk about uniform rules in this field of law, ${ }^{7}$ and the only thing we could do to distinguish some aspects to classify these models. ${ }^{8}$

From our perspective the most important aspect of classification is participation, on which we could distinguish three systems: opt-out, opt-in systems and systems which are mixtures of the both aforementioned systems. While opt-in systems based on expressed participation, opt-out model considers everybody the member of the class who are corresponding the criteria of well-defined class. These members would have to exert activity if they would leave the class.

\subsection{Opt-out system}

The opt-out system, or also called public enforcement is more effective in cases of cease and desist violations of law, as in the case of indemnification. Usually it consorted with active judicial case management. The main point of this system is that the plaintiff, in the name, but without the authorisation of the members of a class is a

4 Bencsik 2014, 655-656; and Harsági Viktória: A kollektív igényérvényesítés fejlesztési lehetőségei, Acta Univ. Sapientiae, Legal Studies, 2015/4, 217-218.

${ }^{5}$ See The Commission 2013/396/EU Recommendation on common principles for injunctive and compensatory collective redress mechanisms in the Member States concerning violations of rights granted under Union Law (2013/396/EU).

6 See Bencsik 2014, 658-660; Harsági 2015, 220-223; and Dave Roos: How Class Action Lawsuits Work in: https://money.howstuffworks.com/class-action-lawsuits1.htm (31.10.2017)

${ }^{7}$ See Harsági: A modellválasztás dilemmái a kollektív igényérvényesítés hazai szabályozásánál, Eljárásjogi Szemle, 2016/1, 25-26.

8 See detailed in Bencsik 2014, 657-658. 
person or an association entitled by law, and the binding force of taken judgement extends ipso iure to the well-defined members of the group without being at law. The right of initiating the procedure is often exercised by non-profit organisations, associations, in some jurisdiction labour organizations, professional chambers, prosecutors, and in Scandinavian countries the consumer ombudsman. Their purpose is to enforce the (public)interests defined by law, and not the rights of individual class members. ${ }^{9}$

Opt-out system seems more radical then the opt-in system, so it is applied in less European countries, and these countries try to limit the scope of application too. Critics mostly complain about members of the class do not get appropriate information about the case, and the inactivity is considered as permission to be represented by the representative plaintiff and that is the cause they do not grab the opportunity to optout, which could be considered as the violation of right to be heard and their autonomy. ${ }^{10}$ Legal literature emphasizes parties have to have the opportunity to decide if they would like to take part in a procedure which has an effect on their substantive rights or representation, because these questions may result in constitutional problems and the violation of right to fair trial. ${ }^{11}$ According to others these rights are granted by the opportunity to opt-out on the other hand. ${ }^{12}$ But the biggest advantage of this system is strenghtening access to justice, not to mention that the total value of claims may be clearly defined and the distribution between individuals is also clear. ${ }^{13}$

\subsection{Opt-in system}

In this system the person of plaintiffs is known and identified. Still the basis of collective litigation is that the court has to judge one typical claim, i.e. one legal and factual ground to be enforced, not all the claims of plaintiffs one-by-one. The effectiveness of opt-in system is arisen from the fact, that all members of the class considered being plaintiffs, but they cannot exercise procedural rights particularly. Moreover, this leads us to other important questions in these types of cases, namely the person of representative plaintiff and the instruction given him by plaintiffs. This model has several advantages, e. g. members of the class are fix in person, the respect of party autonomy, etc. But the disadvantage is whether sufficient number of plaintiff are joined the class or not? ${ }^{14}$

\footnotetext{
${ }^{9}$ Harsági 2016, 26-27.

${ }^{10}$ Harsági 2015, 219.

${ }^{11}$ Harsági 2015, 225-226.

12 Nagy Csongor István: The European Collective Redress Debate After The European Commission's Recommendation - One Step Forward, Two Steps Back?, Maastricbt Journal Of European And Comparative Law, 2015/4, 537.

${ }_{13}$ Harsági 2016, 29.

14 Harsági 2016, 29.
} 


\section{Collective redress in the new Hungarian Code of Civil Procedure}

The introduction of collective redress into the Hungarian legal system is not a new idea, since the T/11332. Bill of 2010 also proposed the introduction of group litigation, but this bill failed. ${ }^{15}$ The establishment of this new legal institution was the effect of codification of the new civil procedure. The Government decided on a comprehensive codification of civil procedure in its government decree 1267/2013 (17.V). According to the governance the purpose of review was to create a modern Code of civil procedure, which corresponds to international practice and expectations, ensures effective enforcement of substantive rights, and upon which the results of jurisprudence and judicial precedent regulates procedural questions in a clear, coherent way, attention to technical achievements, making it easier for the citizens seeking legal advice and legal professionals to litigate. After extensive preparatory work the new Act on Civil Procedure was adapted on the 22th of November, 2016, and two types of collective redress mechanism, public enforcement and collective litigation became the part of Act CXXX of 2016.

Currently the civil procedural rules in force know only the institution of actio popularis. Gelencsér defined public enforcement as it aims to settle the disrupted balance between litigants in private law cases and to reach the most effective legal protection, it is an instrument of legal protection to facilitate public or community interest, which is applicable only by organisations authorised by law, which results in a decision has legal effect to all the parties who are not litigating, but (materially) interested, in the case of successful vindication. ${ }^{16}$ The constitutional basis of right initiate procedure defined in a particular act is public interest, or the circumstance that in these actions the authorised organisation enforces a kind of private interest others not initiated, which becomes public interest by its difficulty or obstacles of enforcement other's interest. ${ }^{17}$

\subsection{Public enforcement}

The procedural rules of public enforcement is applied if the act, gives the authorisation to submit a claim to protect public interest, ${ }^{18}$ prescribes that this kind of action shall be conducted upon these rules. ${ }^{19}$ Now there are several authorisations to submit a claim to protect public interest and they cover many fields of law, so it is inadvisable to give a uniform definition of public enforcement. Some public enforcement actions initiated by the prosecutor, others by administrative bodies,

\footnotetext{
${ }^{15}$ Bencsik 2014, 654.

16 Gelencsér Dániel: Közérdekű igényérvényesités Magyarországon I. - a gyakorlat tükrében, Eljárásjogi Szemle, 2016/3, 32.

17 Gelencsér 2016, 32.

18 There are more Act in force also, but we mention those relevant for our topic: Act LIII of 1995 on the General Rules of Environmental Protection (hereinafter: Kvt.), Act LIII of 1996 on the Protection of Nature

19 Pp., $\int 571$.
} 
furthermore in some cases by associations too. Some of these actions are declaratory actions, others are creating legal relations, still others condemnatory upon legal authorisation. Because of this complexity we could not give a summarised procedural content description on the basis of which we could decide if an authorisation falls within the scope of definition or not. For this reason, it serves legal certainty better if the special act gives the authorisation to submit the claim also orders to apply the provisions of this chapter of the Code. ${ }^{20}$

We have to emphasize those persons' in the name of the action was brought will not be litigants. ${ }^{21}$ At the same time, autonomy of the parties excludes to make a judicial binding decision against their will, which is why special acts granting the right to submit a claim states that public enforcement does not affect individuals' right to claim. ${ }^{22}$ But the plaintiff shall to name the entitled persons in his claim and the way of proof they could justify they are members of the class so the provisions of judgement are applicable to them. ${ }^{23}$ This practically means the definition of those circumstances upon which members of the class could be identified. The congeniality of entitled persons necessarily means the congeniality the right to be enforced and facts establishing this right. ${ }^{24}$ If the way of proof class membership cannot be defined uniformly or according to the judge there is no way of proof, which could be applied uniformly, procedure shall be dismissed ex officio. ${ }^{25}$ The plaintiff could be in a proof and statement of emergency in connection with justification, while only the defendant knows the relevant circumstances in some case. This proof of emergency shall be solved on the basis of general rules of the Code. Clearly, the judge is not bound by the statements of claim, so the determination of both the entitled class and the way of proof could be part of the case, in which judge shall decide at the end, but only within the limits of the claim. ${ }^{26}$

In the procedure declaratory action is permitted if unified condemnation is not possible because the sum of condemnation is different per head, but the right to be declared is the same. ${ }^{27}$ The legitimacy of this special declaratory claim is that it is not possible to judge the sum of condemnation within one evidentiary process for every member of the class, so it could be condemned after start an individual action. ${ }^{28}$

\footnotetext{
20 Arguing to the Act CXXX of 2016, \ 571-572; and Wallacher Lajos: A kollektív igényérvényesítéssel kapcsolatos perek, in: Wopera Zsuzsa (edit.): Magyarázat a polgári perrendtartásról szóló 2016. évi CXXX. törvényhez, Wolters-Kluwer, Budapest, 2017, in: https://uj.jogtar.hu/\#doc/db/384/id/A17Y1559.KK/ts/20161202/ (10.10.2016)

${ }^{21}$ Pp., $\ 573$ (2).

22 Wallacher 2017.

${ }^{23}$ Pp., $₫ 574$ (1).

24 Wallacher 2017.

25 Pp., $\int 575$.

26 Arguing to Pp., $\ 574$.

27 Pp., $₫ 574$ (3).

28 Wallacher 2017.
} 
The Code was created two different types of dismissing procedure, to which refusal of the claim is not related, because same congeniality is not a precondition of the action (while there are cases of public enforcement which do not even have a real class behind), rather it is to be a subject to debate and evidence procedure. However, in this case the claim incorporated in a public enforcement claim would be impractical and unsuccessful, not the claim is ungrounded, so it should not be dismissed in a judgement. There is a place for dismissal of the proceeding when the preconditions wrote in the general part of the Code are not satisfied after amending the statement. A special type of amendment is to convert condemnatory claim to declaratory claim.

This is also true to the way of justification of the membership, which is kind of an evidential question and has two cases of successfulness: when the way of proof marked by the plaintiff is unsuccessful in one hand, and when this way is effective but it cannot be applied uniform to all the members of the entitled class on the other. The requirement of uniformity has not violated if the plaintiff marks not only one way of proof or justification, but two or more, and each one is applicable for a subcategory of the class. In other words, the way of justification shall be categorical but it could contain some kind of differences in point of the members of the class if the main conditions expected by law of public enforcement are stand: essential congeniality of facts and legal argument. ${ }^{29}$

In the judgement of a public enforcement we also shall define the entitled class and the way of justification. ${ }^{30}$ The losing defendant shall be judged to make payment to the entitled members of the group, but court costs are judged to the plaintiff. ${ }^{31}$ For the avoidance of confusion the Code regularizes the personal scope of the judgement. ${ }^{32}$ As we mentioned before, after the public enforcement procedure members of the class have the opportunity to submit an individual claim, but in this case individual plaintiff shall enclose a simple statement to his claim. So the Code take out from its scope only those class members who have declared that kind of wills, ${ }^{33}$ thereto they have to be notified about the judgement. This shall be accomplished by the defendant, since he knows the members of the group on one hand, and on the other hand it is in his favour to know if there would be individual claims against him or not. Class members answer the defendant if they would maintain the right to sue within the regular statute of limitation or not. In the case the entitled class member did not get the notification and bring an individual claim the defendant would call the entitled person to make the statement within this case who either carries on the case, or accepts the judgement of the public enforcement case and abandons the action or the court would dismiss proceeding. The Code clearly declares that the judgement of public enforcement has binding force in relation to the defendant, is that he cannot bring individual claims against the entitled class members to prevent the completion of the judgement. ${ }^{34}$

${ }^{29}$ Arguing to Pp., $\int 575$.

${ }^{30}$ Pp., $₫ 577$ (1).

${ }_{31}$ Pp., $\int 577$ (1)-(2).

32 Pp., $\int 578$.

33 I.e. opt-out model.

34 Wallacher 2017. 
But on the other hand the Code does not settle the situation when the claim of the plaintiff is dismissed by the regional court. Probably aspects of procedural economy won't prevail in these cases, because entitled members are not interested in joining this kind of judgement, so mass of individual claims are expected in this case.

\subsection{Collective litigation}

Introduction of collective litigation into the Hungarian legal system beside public enforcement is reasonable because the Code does not allow public enforcement for any kind of cases. While in the case of public enforcement action is started without the approval of real entitled persons by substantive law (which as we mentioned before could be legitimated by a significant social or public interest), thus collective litigation accomplishes the objective of procedural economy by the full respect of party autonomy. 35

The Chapter on collective litigation contains only the necessary ruling differ from the general rules, because in many cases application of general rules of the Code is appropriate in this type of actions, e.g. jurisdiction of court, litigated amount, etc. But the Code obligates legal representation, which is justifiable procedures conducted by district courts. ${ }^{36}$

According to the Code collective litigation is a kind of collective redress in which the decision and explicit declaration of entitled persons forms the basis for claims could be judged together in one action, so it realizes opt-in system. The right of at least ten plaintiffs ${ }^{37}$ which are the same in content could be vindicated within the form of collective litigation. This common right of the plaintiffs called representative right. We could talk about collective litigation if the facts, so called representative facts, establishing representative right are common in connection with all the plaintiffs and the court has approved the form of collective litigation. Another condition that only in the cases taxated by the Code could the plaintiffs decide to claim their right in the form of collective litigation: namely claims arising from consumer contract, labour actions and claims for health damages and property damages directly caused by unpredictable environmental load based on human activity or omission. ${ }^{38}$ It is clear out of the explanation of the Code that probably in these cases individual claims won't be submitted to the court so without the advantages of collective redress legal protection would come to nothing that is why these types of action are nominated is the new Code. ${ }^{39}$

\footnotetext{
35 Arguing to the Act CXXX of 2016, \582.

36 Arguing to the Act CXXX of 2016, $\int 582$.

37 There is no maximum numer of plaintiffs, but in the case of unmanageably large number of plaintiffs could be result in the dissmiss of claim.

38 Pp., $\int 583$ (2).

39 Arguing to the Act CXXX of 2016, $\int 585$.
} 
Plaintiffs shall declare their intent to apply the rules of collective litigation even in their claim, and they shall name the collective plaintiffs, the base of their partnership, the person of (vice)representative plaintiff, the authorisation given to the legal representative, the representative right, the representative facts, the determination of way of justification of every plaintiff is a kind of person representative facts and rights are stand for, and the collective litigation contract of the plaintiffs. ${ }^{40}$ In the case of a condemnatory action claims of the plaintiffs shall be defined per capita.

If the legal conditions of collective litigation are not prevailing anymore court shall dismiss the application for authorisation, in other cases authorisation shall be permitted. This decision could be make within maximum of sixty days from the submission of the claim but at least together with closing of preparatory stage. In the ruling permitting collective litigation shall define the representative right in question, the representative facts and the way of justification of causation and its deadline. In the case of refusal of authorisation, action shall be dismissed at the same time. The extension of legal effect upon lodging a claim exists in relation to those plaintiffs who submit their claim within 30 days from the ruling come into force individually or according to the rules of collective litigation, or validate their claims by other means. ${ }^{41}$

In collective litigation the rights of plaintiffs shall be exercised by the representative plaintiff alone. Any kind of limitation of these rights of the representative plaintiff by the collective litigation contract does not have an effect on validity and scope of statements, legal actions of the representative plaintiff. The procedural rights of plaintiffs are uniform and could be practiced uniformly. ${ }^{42}$

The collective litigation contract incorporates the will of plaintiffs not entitled to act in the procedure. This contract contains how should be the procedure conducted, how the rights and obligations shall be exercised and procedural provisions in the sense that it establishes the background of procedural rights and obligations exercised by the representative plaintiff. So it is not incompatible to draft contractual rules in a procedural act. ${ }^{43}$ The contract shall be put in writing, and the Code regulates the questions parties have to regulate the contract to be operable and fair. ${ }^{44}$

Only in the preparatory stage may new plaintiffs enter into the collective litigation or leave it with the approval of the court. Only the representative plaintiff could apply for these kind of actions on one occasion aggregated. ${ }^{45}$ It is useful to allow post-joinder since it is possible that organisation of the class is not terminated at the time the claim was submitted. On the other hand, the identity and rights of class members effect on representative rights and facts which determination is the first step of preparation of the case so it cannot be allowed without any limitation of time.

\footnotetext{
${ }^{40}$ Pp., $\int 584$ (1).

${ }^{41}$ Pp., $\int 585$.

42 Pp., $\int 589$.

43 Arguing to the Act CXXX of 2016, $₫ 586$

${ }^{44}$ Pp., $\int 586$.

45 Pp., $\ 587$.
} 
But this is not violating the autonomy of possible plaintiffs since they still have the opportunity to submit an individual claim, they lose only the opportunity to sue within a collective form. Implicitly it is necessary to amend collective litigation contract appropriate. We have to notice that permitting joinder or leaving is not mandatory to allow in the contract. ${ }^{46}$

Court judges the claim unified upon the patterned fact based on the representative facts and rights. The defendant is condemned in favour of those plaintiffs for whom the justification of conjugation was made in time. Representative plaintiff shall be condemned to pay or entitled to get court costs. ${ }^{47}$

Both within the rules of public enforcement and collective litigation if upon the complexity of the case it is reasonable three professional judges may proceed in these cases. ${ }^{48}$ But in the case of collective litigation only if the case regional court acts in the first instance. 49

We shall mention the expert suggestion proposed a different ruling to the system of collective redress. According to the suggestion the chapter of collective redress would contain three types of actions. The first one is actio popularis which would keep the rules of the Act III. of 1952. The second one is collective litigation as the archetype of collective redress as an opt-in model without any restriction of subject matter, but mainly applied in cases where individuals enforce their specified claim of damages within one procedure. The cases should have the same legal ground, but in the sense of amount they could proceed as individual claims. And thirdly the class action as an opt-out model applied only in a narrow area of substantive law to reduce the number of abuses. Common facts and legal base and a minimum number of class members are provided. The class should be treated as a unit till the end of execution. The defendant should pay a sum of money to the class, which would be divided upon an allocation plan made by the representative or a civil association. ${ }^{50}$

\section{The applicability of collective redress in environmental matters}

János Sári said speciality of protection of the environment consists in humanity and environment could be its object. ${ }^{51}$

In the terminology of the Act LIII of 1995 on the General Rules of Environmental Protection (hereinafter called Kvt.) environmental impact means the direct or indirect emission of a substance or energy into the environment. ${ }^{52}$ According to the act in force in the event the environment is being endangered, damaged or polluted, environmental protection associations are entitled to file a lawsuit against the user of the environment requesting the court to enjoin the party posing the hazard to

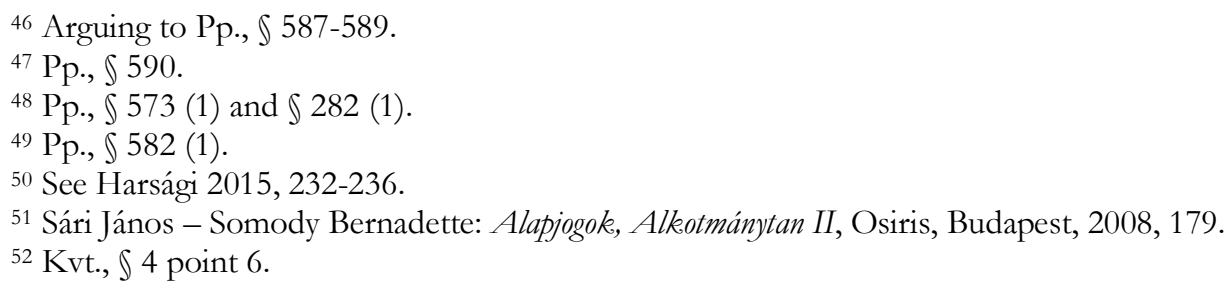


refrain from the unlawful conduct or compel the same to take the necessary measures for preventing the damage. ${ }^{53}$ Furthermore, in the event of endangerment of environment, the prosecutor is also entitled to file a lawsuit to impose a ban on the activity or to elicit compensation for the damage caused by the activity endangering the environment. ${ }^{54}$ That will also be the situation after $1^{\text {st }}$ of January, 2018, so public enforcement claims could be submitted by the environmental protection association and by the prosecutor due to Kvt. Kvt. defines the prosecutor's right to submit the claim narrower in the cases described in section 101, the scope of legal consequences applicable upon an offending activity. Polluters of the environment shall bear liability for the impact of their activities upon the environment in the manner governed in this Act and in other legal provisions. He shall refrain from engaging in any activity posing imminent threat or causing damage to the environment, where environmental damage has occurred, to restore damaged natural resources and to take measures to restore the baseline condition. In the event of failure to comply with the requirements set out in Paragraphs a) the court shall limit the activity, or shall suspend or prohibit this activity. From the comparison of cited legal provisions comes that judge can make a decision implied in section 101 of Kvt. on the ground of claim submitted by the prosecutor to ban on activity, namely prohibit the activity causing damage to the environment. This institution is similar to the regulation of section 341 (now 6:523) of the Civil Code, which makes it possible to apply a sanction regulated by law and is applied exceptionally in the case of which it has not occurred but really threatening potential damage. It comes from the provision of law if the risk was elapsed from the nature of this legal relationship the above mentioned prohibition of threatening activity loses its legal basis. In the absence of legal basis according to the second sentence of section 123 of Code of civil procedure in force there is no place of declaratory claims and judgements. We have to evaluate different the prosecutor's declaratory claim in the case of claims for restoring damages occurred by endangering environment. In the cited case the plaintiff successfully referred that the prosecutors right to submit a declaratory claim expands to the condemnation upon the same legal relationship if the additional requirements of the code of civil procedure are applicable. In this case it is also required that claim for damages between the polluter and the prosecutor entitled to submit a claim shall be existing. ${ }^{55}$ In the cited case the prosecutor claims for prohibition the activity causing damage, instead of compensation, so Curia upheld the dismissal. Natural persons are not entitled to submit a claim, as Curia stated in its judgement. ${ }^{56}$

In accordance with collective litigation the bill contained only the first and second cases, and it has been expanded to environmental cases upon the initiation of the Deputy Commissioner Protecting the Interest of Future Generations of Commissioner for Fundamental Rights during the parliamentary debate.

\footnotetext{
53 Kvt., \98-99; Gyimesi Tamás Ferenc: A res iudicata a kollektív igényérvényesítés tekintetében, Iustum Aequum Salutare, 2015/2, 180.

${ }^{54}$ Kvt., $₫ 109$.

${ }^{55} \mathrm{EBH} 2000,321$.

56 BH 2007, 259; and EBH 2006, 1418.
} 
His reasons were the following: cost effectiveness is evincible in this types of actions, while there is a possibility of individual actions, but due to unequal distribution of costs it is not started mostly. Only those kind of actions could be included where it is typical that there is common legal and factual basis which justify the possibility of interconnection because of the characteristic of substantive claims. The scope of this kind of claims is hardly limited: is could be traced back to an environmental load causes health deterioration or property damage to the group of plaintiffs, injured parties could not have foreseen it, i.e. they are outside normal operation, and are consequences of human activity or omission. ${ }^{57}$ In practical, disaster like, unforeseen, unlawful environmental load claims could be enforced in collective claims.

The Code however directly does not apply the definition of environmental load as right to collective litigation, but the damages resulting from environmental load. The sum of damage or restitution could be different per head, which indicates some kind of individualisation, e.g. determining the degree of health damage by expert examination. But this should be happen after judging the legal base. In addition, after the condemnation of responsibility amicable settlement comes into the view of the parties. Under Kvt. the user of environment shall bear liability for the impact of his activity or omission upon environment according to criminal and civil law, and administrative provisions.

Under Kvt. damage caused to other parties by virtue of activities or negligence entailing the utilization or loading of the environment shall qualify as damage caused by an activity endangering the environment, and the provisions of the Civil Code on activities entailing increased danger shall be applied.

\section{Summary}

In conclusion, also pointing out the importance of this theme, we would like to give some thoughts about the EU aspects of this question. As we have mentioned in the introduction, the right to healthy environment is considered as fundamental right, so it is not surprising it is protected by international conventions and EU law. For our topic the Aarhus convention ${ }^{58}$ has an enthusiastic importance, and one of its keyquestions is the wide providing of access to justice for the public in environmental cases. While the damage to environment has a speciality that while the individual damages are low, the cost and risk of litigation are high, so the Convention concluded by the EC in 2005, protects primarily not the rights of individuals but the public interest. The right of access to justice is realised mainly and effectively though submitting a case by organisations authorised by national laws, even when the deraign of final decision in a collective redress serves primarily not the rights of individuals but the public interest. ${ }^{59}$

\footnotetext{
57 Wallacher 2017.

58 Aarhus Convention on Access to Information, Public Participation in Decision-Making and Access to Justice in Environmental Matters, was adopted on 25 June 1998.

${ }^{59}$ Mariolina 2014, 257-266.
} 
Besides in many states, e. g. in Hungary, prosecutor is also entitled to submit a case. We may be worth emphasizing, that private individuals are not entitled for the initiation of these proceedings, because in such cases they are likely to be unable to effectively enforce their interests by considering the risk and expected profits. From this approach we could felt to be applicable basically the rules of public enforcement, but in my opinion the frame of collective litigation is also comply with the Convention, if we could consider the joinder plaintiffs as authorised by law to submit a case, or even easier if environmental association would named as representative plaintiff.

We can see that the rules of new Code of Civil Procedure on collective redress together with the authorisation given by the Kvt. are applicable to validate damages caused to the environment in a European manner. 


\section{TóTH Barbara* \\ A kollektív igényérvényesítés, mint új eljárásjogi jogintézmény alkalmazhatósága környezet védelmében ${ }^{* *}$}

A class action a méltányosság találmányának tekinthetö, ugyanis a class actoin megszületését az a

gyakorlati szü̈kségesség elözte meg, mely szerint nélkülö̧̈hetetlen egy olyan eljárásjogi eszköz, mely segitségével a nagyszámú peres felekboól álló, közös érdekeltségü csoportok nem lesznek megakadályozva abban, hogy méltányos jogaikat érvényesithessék. ${ }^{1}$

\section{Bevezetés}

Az egészséges környezethez való jog alapjogként érvényesül, így alkalmazandó rá a szükségességi-arányossági teszt. Az Alkotmánybíróság a jogot a 18/1994. (V. 20.) $\mathrm{AB}$ határozatában értelmezte máig irányadóan. Ennek rendelkező részében kimondta, hogy az egészséges környezethez való jog azt a kötelezettséget is magában foglalja, hogy az állam a természetvédelem jogszabályokkal biztosított szintjét nem csökkentheti. Az Alaptörvény alkotmányi szintre emeli azt a szabályt, amely szerint a környezeti károkozás esetén a károkozót helyreállítási kötelezettség terheli, amely a szennyező fizet elvének megjelenése. Az elv összekapcsolható az Alaptörvény P) cikkében kifejtettekkel is, amely által a jogalkotó itt már a környezet megóvásának egyes konkrét kötelezettségeit is megfogalmazza, amely mindenki számára kötelező. Szintén ugyanez a határozat mutatott rá arra is, hogy a környezeti károk megtérítésének a kötelezettsége a tulajdonvédelem szabályaiból is fakad, de az egészséges környezethez való jog szoros összefüggésben áll az élethez való joggal is. A jog érvényre juttatását az állam többirányú intézkedéssel is biztosítja, így a környezetvédelmi szabályok megalkotásával, vagy az alapvető jogok biztosának jövő nemzedékek védelmét szolgáló helyettesével. ${ }^{2}$

A környezetben okozott károk esetén tipikus, hogy az egyéni kárigények (relatíve) alacsonyak, ám összességükben igen jelentősek. Csekély jelentőségú követelések esetén, azaz amikor a perlekedésből várható előnyök nem haladják meg az azzal járó várható hátrányokat, költségeket, nem biztos, hogy a peresekedés hasznos megoldást jelent, ${ }^{3}$ így ha a károsultaknak egyenként kellene az igényeiket érvényesíteni,

* dr. jur., egyetemi tanársegéd, Miskolci Egyetem, Állam- és Jogtudományi Kar, Polgári Eljárásjogi Tanszék, e-mail: toth.barbara90@gmail.com

** A tanulmány az Igazságügyi Minisztérium jogászképzés szinvonalának emelését célzó programjai keretében valósult meg.

${ }^{1}$ Montgomery Ward \& Co. v.Langer, 168 F. 2d 182, 187 (8 $8^{\text {th }}$ Cir. 1948).

2 Kommentár Magyarország Alaptörvényéhez, XXI. cikk, Wolters-Kluwer, in: https://uj.jogtar.hu/\#doc/db/1/id/A1100425.ATV/ (2017.10.10)

${ }_{3}$ Bencsik Klaudia: A class action eredete és kialakulása a polgári perjogi kodifikáció tükrében, in: http://epa.oszk.hu/02600/02687/00006/pdf/EPA02687_jogi_tanulmanyok_2014_654663.pdf (2017.11.15.) 2014. 655. és Mariolina Eliantonio: Collective Redress in Environmental 
az valószínűleg csökkentené a hatékony igényérvényesítést. A kollektív igényérvényesítés révén azonban a felpereseknek nem kell lemondania a jogi képviselet lehetőségéről, növelve ezzel a pernyertesség valószínűségét is, továbbá az alperes jövőbeni magatartására is kedvező hatással lehet, nevezetesen elrettenti ôt a jövőbeni jogsértésektől. A feleken kívül az igazságszolgáltatás számára is csak előnyökkel jár: a bíróságok munkaterhe csökken, csökkennek az adminisztratív költségek és az ítélkezési gyakorlat is egységesebb lesz általa. ${ }^{4}$

A kollektív igényérvényesítés meghonosítása a magyar jogban nem újkeletű gondolat, ám csak az új polgári perrendtartás megalkotásával sikerül elérni ezt az Európában is egyre nagyobb jelentőséggel bíró igényérvényesítési módot. ${ }^{5}$ Tanulmányomban először a kollektív igényérvényesítés két alaptípusát, az opt-in ill. az opt-out modellt ismertetem. A második részében a 2018. január 1-től hatályos szabályokat, melyeket az új Pp. vezet be a magyar jogba, végül pedig azokat a környezetjogi pereket, ahol a két új igényérvényesítési mód alkalmazható.

\section{A kollektív igényérvényesítés (alap)típusai - az opt-in és az opt-out rendszer bemutatása}

Azért is szükséges kitérnünk a létező rendszerek ismertetésére, hiszen igaz, hogy valamennyi csoportos perlési modellnek az amerikai class action tekinthető a kiindulópontjának, ${ }^{6}$ azonban az amerikai rendszer egyetlen másik országban sem létezik tiszta formájában, és Európában csak különböző hibrid változataival találkozhatunk, emiatt nem is beszélhetünk egységes szabályokról a témával kapcsolatban. ${ }^{7}$ Csupán olyan szempontokat tudunk megkülönböztetni, ami alapján csoportosítani tudjuk az egyes modelleket. ${ }^{8}$

Számunkra a legjelentôsebb csoportosítási szempont a perlésben való részvétel, mely alapján három modellt tudunk megkülönböztetni: opt-in, opt-out és vegyes rendszerek, melyek az előző kettő elemeit vegyítik különböző mértékben. Míg az előbbi a részvétel kinyilvánításán alapul, addig az utóbbi eleve a csoport, osztály tagjainak tekinti azokat, akik az osztály pontosan körülhatárolt megfogalmazásának megfelelnek, ők aktivitásukat akkor kell, hogy kifejtsék, ha nem szeretnének az osztályban maradni.

Matters in the EU: A Role Model or a 'Problem Child'?, In: Legal Issues of Economic Integration 2014/3, 257-259.

4 Bencsik 2014, 655-656. és Harsági Viktória: A kollektív igényérvényesítés fejlesztési lehetőségei, Acta Univ. Sapientiae, Legal Studies, 2015/2, 217-218.

${ }^{5}$ Ld. A Bizottság 2013/396/EU ajánlása (2013. június 11.) az uniós jog által biztosított jogok megsértése tekintetében a jogsértés megszüntetésére és kártérítésre irányuló tagállami kollektív jogorvoslati mechanizmusok közös elveiről.

${ }^{6}$ Ld. Bencsik 2014, 658-660.; Harsági 2015, 220-223. és Dave Roos: How Class Action Lawsuits Work, in: https://money.howstuffworks.com/class-action-lawsuits1.htm (2017.10.31.)

${ }^{7}$ Ld. Harsági: A modellválasztás dilemmái a kollektív igényérvényesítés hazai szabályozásánál, Eljárásjogi Sžemle, 2016/1, 25-26.

${ }^{8}$ Ld. részletesen Bencsik 2014, 657-658. 


\subsection{Az opt-out rendszer}

Az opt-out modelleket nevezik még public enforcementnek, vagy magyar fordításban közérdekű pernek is. Ez a lehetőség sokkal hatékonyabbnak bizonyul a jogsértések megszüntetése, ill. megelőzése iránti pereknél, mint a kártérítés területén. Általában aktív bírói pervezetéssel társul. Lényege, hogy az eljárást egy a jogszabályok által felhatalmazott személy vagy szervezet kezdeményezi a csoport tagjainak nevében, azok kifejezett hozzájárulása nélkül, és a perben hozott itélet jogereje a jól körülhatárolható csoport tagjaira azok perbenállása nélkül, automatikusan kiterjed. Az eljárás kezdeményezésének jogát sok esetben non-profitszervezetek, egyesületek gyakorolják, egyes országokban érdekvédelmi szervezetek, kamarák, az ügyész, a skandináv országokban a fogyasztói ombudsman. Céljuk a törvényben meghatározott érdekek érvényre juttatása, nem pedig elsősorban a tagok jogainak érvényesítése. ${ }^{9}$

Az opt-out modell radikálisabbnak tekinthetô, így kevés európai államban nyert teret, és ezekben az országokban is korlátozzák a hatályát. A kritikusok többnyire azt sérelmezik, hogy ha az osztálytag nem kap megfelelő tájékoztatást a megindult eljárásról, és emiatt nem él az opt-out lehetőségével, abban az esetben az inaktivitást úgy tekintik, mint hozzájárulást ahhoz, hogy a reprezentatív felperes által képviseltessenek, ez pedig sértheti a meghallgatáshoz való jogát és a rendelkezési jogát. ${ }^{10}$ A jogirodalom hangsúlyozza, hogy az egyéneknek meg kell, hogy legyen a lehetőségük annak eldöntésére, részt akarnak-e venni az eljárásban, ami kihat az anyagi jogaikra, érinti perbeli képviseletüket, ugyanis ezek a kérdések alkotmányossági és a tisztességes eljáráshoz kapcsolódó problémákat vethetnek fel. ${ }^{11}$ Mások szerint ezt éppen a kilépés lehetősége biztosítja. ${ }^{12}$ Legnagyobb előnye viszont, hogy az igazságszolgáltatáshoz ez a módszer nyújtja a legjobb hozzáférést, továbbá, hogy a követelések összértéke megállapítható, az egyes károsultak közötti elosztása világos. ${ }^{13}$

\subsection{Az opt-in rendszer}

Ebben a modellben a felperesek személyükben ismertek, azonosítottak. Ennek ellenére a társult per lényege, hogy nem a felperesek egyedi igényeinek összességét (mindegyikét), hanem egyetlen, tipikus igényt, azaz egy érvényesített jogot és egy hozzá tartozó tényalapot bírál el a bíróság. A társult per másik hatékonysági előnye abból származik, hogy a jogosultak ugyan mindannyian felperesek a perben, de perbeli jogokat egyedileg, külön-külön nem gyakorolhatnak. Ebből következően viszont a társult per másik fontos szabályozási tárgya annak meghatározása, hogy a csoport nevében ki jár el, illetve a csoport befolyásolhatja-e a pervitelt.

\footnotetext{
${ }^{9}$ Harsági 2016, 26-27.

${ }^{10}$ Harsági 2015, 219.

${ }^{11}$ Harsági 2015, 225-226.

12 Nagy Csongor István: The European Collective Redress Debate After The European Commission's Recommendation - One Step Forward, Two Steps Back?, Maastricbt Journal Of European And Comparative Law 2015/4, 537.

${ }^{13}$ Harsági 2016, 29.
} 
Az opt-in modellnek számos előnye van, pl. az osztálytagok személyének biztossága, hogy a felek szabad akaratukból csatlakoznak a csoporthoz. Hátránya viszont pont ebből adódik, sikerül-e elérni a megfelelő részvételi arányt. ${ }^{14}$

\section{Kollektív igényérvényesítés az új Pp.-ben}

A kollektív igényérvényesítés bevezetése a magyar polgári perjogba nem újkeletű gondolat, hiszen már a 2010-es T/11332. törvényjavaslat is indítványozta a csoportos keresetindítás bevezetését, e javaslat azonban mégsem vált a magyar polgári eljárásjog részévé. ${ }^{15}$ A jogintézmény meghonosodására az új polgári perrendtartás kodifikációja révén került sor. A Kormány a polgári perjogi kodifikációról 1267/2013. (V.17.) Korm. határozatban döntött a Polgári perrendtartásról szóló 1952. évi III. törvény átfogó korszerűsítéséről. A kormányhatározat szerint a felülvizsgálat célja egy korszerű, a nemzetközi gyakorlatnak és elvárásoknak is megfelelő polgári perjogi törvénykönyv megalkotása, amely biztosítja az anyagi jogok hatékony érvényesítését, és amely a jogtudomány és a joggyakorlat eredményeire támaszkodva áttekinthetően, koherensen, a technika vívmányaira is figyelemmel szabályozza a perjogi viszonyokat, megkönnyítve ezzel a jogkereső állampolgárok és a szakmai közönség helyzetét. Hosszas előkészítő munkálatokat követően az új polgári perrendtartásról szóló törvény 2016. november 22 napján elfogadásra került, és a kollektív igényérvényesítéssel kapcsolatos két pertípus, a közérdekből indított per és a társult per, a 2016. évi CXXX. törvény nyolcadik részében kaptak helyet.

A jelenleg hatályos magyar perjog csak az actio popularis intézményét ismeri. A közérdekű per fogalmát Gelencsér úgy határozta meg, hogy a közérdekű kereset a magánjogi jogvitákban érdekelt felek között megbomlott egyensúly kiegyenlítését és a hatékonyabb jogvédelmi hatás elérést célzó, minden esetben jogszabály által feljogosított szervezet által alkalmazható, köz- vagy közösségi érdek elősegítése céljából biztosított jogvédelmi eszköz, melynek sikeres érvényesítése esetén, valamennyi perben nem álló, de érdekelt (materiális) félre kiterjedő hatályú döntést eredményez. ${ }^{16} \mathrm{~A}$ külön jogszabályban meghatározott keresetindítási jog alkotmányos alapja a közérdek, vagy az, hogy ezekben az eljárásokban az erre feljogosított szerv olyan mások általi jogvédelmet nem kezdeményezhető magánjogi érdeket érvényesít, amely igényérvényesítés éppen az egyéb érdekvédelem akadálya vagy nehézsége folytán válik közérdekűvé. ${ }^{17}$

\footnotetext{
${ }^{14}$ Harsági 2016, 29.

${ }^{15}$ Bencsik 2014, 654.

16 Gelencsér Dániel: Közérdekủ igényérvényesítés Magyarországon I. - a gyakorlat tükrében, Eljárásjogi Szemle, 2016/3. 32.

17 Gelencsér 2016. 32.
} 
Tóth Barbara

A kollektív igényérvényesítés, mint új eljárásjogi jogintézmény

alkalmazhatósága környezet védelmében
Agrár- és Környezetjog

2017. 23. szám

\subsection{A közérdekből indított perek}

A közérdekből indított perekre vonatkozó szabályokat akkor kell alkalmazni, ha a közérdek védelme érdekében perindításra felhatalmazást adó törvény ${ }^{18}$ úgy rendelkezik, hogy az ilyen közérdekből indított pert e szabályok szerint kell lefolytatni. ${ }^{19}$ A jelenlegi közérdekű perindítási felhatalmazások sokrétűek, számos jogterületre kiterjedőek, jogalkotási szempontból egységes definíció adása a jelentős számú kivételes jellegű közérdekű perindításra való feljogosítás miatt nem célszerű. Egyes közérdekű pereket az ügyész indít, másokat közigazgatási szervek, sőt bizonyos esetekben egyéb (pl. civil) szervezetek is jogosultak lehetnek perindításra. Egyes közérdekű perek megállapítási vagy jogalakítási típusú jogkövetkezményeket céloznak, ismét mások törvényi felhatalmazás alapján - akár pénzügyi követelés érvényesítésére is alkalmasak. A közérdekű perindítás fogalmának e sokrétűsége miatt nem lehet olyan összefoglaló perjogi tartalmi leírását adni, mely alapján egyértelműen eldönthető lenne, hogy a definíció alá esik az adott felhatalmazás vagy sem. Ezért a jogbiztonságot jobban szolgálja, ha a külön jogszabály - a perlési felhatalmazás megadásával egyidejűleg rendeli alkalmazni e fejezet rendelkezéseit. ${ }^{20}$

Az eljárás résztvevôivel kapcsolatban fontos kihangsúlyoznunk, hogy azok a személyek, akik nevében, vagy akik igénye érvényesítése iránt a pert megindították, nem lehetnek peres felek. ${ }^{21}$ Ugyanakkor a felek autonómiája kizárja, hogy akaratuk ellenére lehessen rájuk nézve kötelező döntést hozni, ezért az egyes perindítási jogot biztosító jogszabályok kimondják, hogy a közérdekű perindítás nem érinti az egyedi perindítási jogot. ${ }^{22}$ A perindításra jogosultnak viszont a keresetlevélben meg kell jelölnie, hogy kik a perrel érintett jogosultak, valamint azt is, hogy milyen módon kell igazolniuk a jogosulti csoporthoz való tartozásukat, ahhoz, hogy az ítéletben foglaltak rájuk nézve alkalmazhatóak legyenek. ${ }^{23}$ Ez gyakorlatilag azoknak a tényeknek, körülményeknek a meghatározását jelenti, melyek révén a csoport tagjai, érintettségük behatárolható, azonosítható. A jogosultak érintettségének azonossága szükségképpen jelenti az érvényesített jog, illetve az ezt megalapozó tények azonosságát. ${ }^{24}$ Amennyiben a csoporthoz tartozás módja nem határozható meg egységesen, vagy a bíróság szerint a nincs olyan bizonyítási mód, mely egységesen alkalmazható, az eljárást hivatalból meg kell szüntetni. ${ }^{25}$

\footnotetext{
18 Ilyen törvényekból több is hatályban van, azonban mi csak a téma szempontjából relevánsakról teszünk említést: 1995. évi LIII. törvény a környezet védelmének általános szabályairól (továbbiakban: Kvt.), 1996. évi LIII. törvény a természet védelméről.

${ }^{19}$ Pp. 571. S.

20 Indoklás a 2016. évi CXXX. törvényhez 571-572. @ és Wallacher Lajos: A kollektív igényérvényesítéssel kapcsolatos perek, in: Wopera Zsuzsa (szerk.): Magyarázat a polgári perrendtartásról szóló 2016. évi CXXX. törvényhez. Wolters-Kluwer, Budapest, 2017. in: https://uj.jogtar.hu/\#doc/db/384/id/A17Y1559.KK/ts/20161202/ (2016.10.10.).

${ }^{21}$ Pp. 573. S (2) bek.

22 Wallacher 2017.

${ }^{23}$ Pp. 574. \ (1) bek.

24 Wallacher 2017.

${ }_{25}$ Pp. 575. S.
} 
Az igazolási mód tekintetében a felperes állítási, bizonyítási szükséghelyzetbe kerülhet, mivel a releváns tényeket adott esetben csak alperes ismeri. E bizonyítási szükséghelyzet megoldása az általános szabályok alapján történhet. Értelemszerūen a keresetlevélben előadottak nem kötik a bíróságot, vagyis mind az érintett jogosulti csoport, mind az igazolási mód meghatározása a jogvita részét képezheti, melyben, végeredményben a bíróságnak kell döntenie, de a közérdekű kereset korlátai között. ${ }^{26}$

A perben megállapításra irányuló keresetnek akkor is van helye, ha egységes marasztalás nem lehetséges, mert a marasztalás összege jogosultanként eltérő, azonban a megállapítani kívánt jog valamennyiük tekintetében azonos. ${ }^{27}$ Ennek a speciális megállapítási keresetnek az adja a létjogosultságát, hogy a marasztalás összegét egyszeri bizonyítási cselekménnyel nem lehetne mindenkire kiterjedően megállapítani, így ennek megállapítására csak egyéni perindítást követően kerülhet sor. ${ }^{28}$

A törvény két speciális eljárás megszüntetési esetet teremt, melyekhez nem kapcsolódik keresetlevél visszautasítási szabály. Ennek oka az, hogy az azonos érintettség jellegét tekintve nem perelőfeltétel (annál is inkább, mert előfordulhat olyan közérdekű per is, amely mögött nem is áll tényleges jogosulti csoport, akik marasztalási igénnyel léphetnének fel), inkább érdemi vita tárgya, és bizonyítást kívánhat. Azonban ilyenkor az igények közérdekű keresetbe foglalása, aggregálása a célszerútlen és sikertelen, nem pedig maga az igény alaptalan, ebből következően az érdemi, ítélettel való elutasítás nem indokolt. Az eljárás megszüntetésnek értelemszerűen akkor van helye, ha az általános szabályok által megengedett kereset-pontosítás vagy változtatás után sem teljesülnek az előírt feltételek. Az ilyen célú változtatás speciális esete a megállapítási keresetre való áttérés.

Ugyanez igaz a csoporthoz tartozás igazolási módjára is, mely egy olyan bizonyítási kérdés, melynek vonatkozásában kétféle sikertelenség fordulhat elő: a felperes által megjelölt igazolási mód alkalmatlan a bizonyításra, illetve alkalmas ugyan, de nem alkalmazható egységesen az érintett jogosultak vonatkozásában. Az egységesség követelményét nem sérti, ha a felperes nem egyetlen igazolási/bizonyítási módot jelöl meg, hanem pl. kettőt, melyek mindegyike az érintett jogosultak külön alcsoportjára alkalmazható. Másként megfogalmazva: az igazolási módnak határozottnak kell lennie, de a perben érintett jogosultak tekintetében tartalmazhat bizonyos eltéréseket, mindaddig, amíg a közérdekű keresetindítás törvényi felhatalmazáson túli alapvető feltétele: a lényegi ténybeli és jogi azonosság fennáll. ${ }^{29}$

\footnotetext{
26 Indoklás 574. \-hoz.

27 Pp. 574. S (3) bek.

28 Wallacher 2017.

29 Indoklás 575. §-hoz.
} 
A közérdekű perben hozott ítéletben ugyancsak meg kell határozni a jogosulti kört és az igazolás módját. ${ }^{30} \mathrm{~A}$ pervesztes alperest pedig az érintett jogosultak javára kell teljesítésre kötelezni, a perköltség azonban a felperest illeti. ${ }^{31}$ A félreértések elkerülése végett a Pp. rendezi, hogy kikre terjed ki a meghozott ítélet anyagi jogereje. ${ }^{32}$ Mint ahogy azt már az előbb is említettük, a közérdekű per lefolytatását követően is megmarad az egyedi keresetindítás lehetősége, de ebben az estben a jogosultaknak a keresetlevélhez egy egyszerű nyilatkozatot kell tennie. Így a jogeróhatás alól csak azokat a jogosultakat vonja ki a törvény, akik ezt a kívánságukat kifejezték ${ }^{33}$, ahhoz viszont, hogy nyilatkozatukat megtehessék, értesíteni kell őket az ítéletről. Ezt az alperesnek kell megtennie, hiszen ő ismeri a jogosultakat, másrészt az ő érdeke megtudni, hogy számíthat-e még egyéni igényérvényesítésre. A jogosultak az értesítésre válaszolva közlik az alperessel, hogy fenntartják egyéni perindítási jogukat, melyre a rendes elévülési időn belül van lehetőségük. Amennyiben a jogosult nem értesült a jogerôs ítéletről, és megindítja az egyéni pert, abban az esteben az alperes az egyéni per keretében hívja fel nyilatkozattételre a jogosultat, aki vagy folytatja a pert, vagy elfogadja a közérdekú perben hozott ítéletet, elállva a keresetétôl, vagy a bíróság fogja megszüntetni a pert. A törvény egyértelművé teszi, hogy a közérdekű perben hozott ítélet az alperes vonatkozásában jogerőhatással bír, így ő semmilyen módon nem indíthat egyéni pereket a jogosultak ellen a közérdekű perben hozott ítélet teljesítésének megakadályozására. ${ }^{34}$

\footnotetext{
${ }^{30}$ Pp. 577. \(1) bek.

31 Pp. 577. S (1)-(2) bek.

32 Pp. 578. \ (1) A közérdekű perben hozott ítélet anyagi jogerőhatással rendelkezik az alperes új keresetindítása vonatkozásában, továbbá az érintett jogosultak közül azoknak az új keresetindítása vonatkozásában, akik esetében a következő feltételek teljesülnek:
}

a) az alperes az érintett jogosultat az íélet közlésétől számított harminc napon belül egyedileg, írásban értesíti a perben hozott jogerős ítéletről,

b) az alperes az értesítésben tájékoztatást ad arról is, hogy az ítélet anyagi jogerőhatása az érintett jogosultra is kiterjed, kivéve, ha a jogosult az értesítés kézhezvételétől számított hatvan napon belül írásban bejelenti az alperes számára, hogy az egyéni keresetindítás jogát fenn kívánja tartani, és

c) az érintett jogosult nem tette meg a b) pont szerinti bejelentést.

(2) Az érintett jogosultak közül azokat a jogosultakat, akiket az alperes személyesen nem értesített az (1) bekezdésben meghatározott módon, úgy kell tekinteni, mint aki az egyéni keresetindításhoz való jogát fenntartotta.

(3) Ha érintett jogosultnak minősülő személy által indított egyedi vagy társult per a közérdekú perben hozott ítélet jogerőre emelkedése előtt jogerősen nem fejeződött be, az (1) bekezdés szerinti értesítést az alperes e per keretében tett nyilatkozattal köteles teljesíteni, melyre a felperes harminc napon belül köteles nyilatkozni. A bíróság a felperesi nyilatkozat alapján határoz az eljárás további menetéről.

(4) Ha a felperes nyilatkozata alapján a közérdekű perben hozott ítélet anyagi jogerőhatása az egyedi vagy társult perre is kiterjed, a bíróság az eljárást hivatalból megszünteti. Ha a közérdekú perben az alperes pervesztes lett, az egyedi vagy társult per megszüntetésekor az alperest kell a perköltség megtérítésére kötelezni.

33 Azaz az opt-out modell érvényesül.

34 Wallacher 2017. 
A másik oldalról viszont a törvény nem rendezi a helyzetet, tehát amikor a közérdekű perben a felperes kereseti kérelmét elutasítja a törvényszék. Vélhetően ezekben az estekben a pergazdaságossági szempont nem fog érvényre jutni, ugyanis a jogosultaknak nem áll érdekében, hogy egy ilyen tartalmú ítélethez csatlakozzanak, így egy ilyen tartalmú ítéletet követően az egyéni keresetindítások tömege várható.

\subsection{A társult perek}

A társult per formájának bevezetése azért indokolt a közérdekű perek mellett, mert a jogalkotó a közérdekű perindítást csak bizonyos esetcsoportokban teszi lehetővé. Amíg a közérdekű perben a valódi anyagi jogosult ilyen irányú döntése nélkül indul meg a per (amit jelentős részben az igazol, hogy a per megindítása elsősorban társadalmilag jelentős érdek), addig a társult per a rendelkezési jog teljes fenntartásával valósítja meg a perökonómiai célt. ${ }^{35}$

A társult perről szóló fejezet csak az általános szabályoktól való szükségképpeni eltéréseket tartalmazza. Számos esetben az általános szabályok alkalmazása ebben a pertípusban is megfelelő eredményre vezet. Így pl. nincs speciális szabály a hatáskörre, miként a pertárgyérték számításra sem. Kimondja viszont a törvény a kötelező jogi képviseletet, azért, mert ez ebben a speciális pertípusban a járásbíróság előtt is indokolt. ${ }^{36}$

A törvény szerinti társult per a kollektív igényérvényesítés olyan formája, melyben a jogosultak döntése és kifejezett nyilatkozata képezi annak alapját, hogy az igények együttesen, egyetlen perben legyenek elbírálhatók, így az opt-in modellt valósítja meg. Legalább tíz felperes ${ }^{37}$ egy vagy több olyan jogát, amely tartalmában azonos valamennyi felperes vonatkozásában, társult per formájában érvényesítheti. A felperesek e közös jogát reprezentatív jognak nevezzük. Társult perről csak akkor beszélhetünk, ha a reprezentatív jogot megalapozó tények, az ún. reprezentatív tények, érdemben valamennyi felperes vonatkozásában azonosak, és a társult pert a bíróság engedélyezi. További feltétel, hogy csak a Pp-ben taxatíve felsorolt perekben dönthetnek úgy a felperesek, hogy társult perben kívánják az igényeiket érvényesíteni: fogyasztói szerződésből eredő követelés érvényesítése; munkaügyi perben; vagy emberi tevékenységen vagy mulasztáson alapuló, előre nem látható környezetterhelés által közvetlenül okozott egészségkárosodásból fakadó igények vagy vagyoni kárigények érvényesítése esetén. ${ }^{38}$ A törvény indoklásából egyértelművé válik, hogy azért ezek a perek kerültek nevesítésre, mert jellemzően ezekben a jogvitákban egyéni perindításra valószínúleg nem kerülne sor, így a kollektív jogérvényesítés által biztosított hatékonysági előnyök nélkül a jogvédelem meghiúsulhatna. ${ }^{39}$

\footnotetext{
35 Indoklás a 2016. évi CXXX. törvény 582. \-hoz.

${ }^{36}$ Indoklás a 2016. évi CXXX. törvény 582. \$-hoz.

37 A törvény a felperesek számának felső határát nem szabja meg, viszont kezelhetetlenül nagy számú felperes megjelölése a társult per engedélyezésének megtagadását eredményezheti.

38 Pp. 583. § (2) bek.

39 Indoklás a 2016. évi CXXX törvény 585. \-hoz.
} 
A felpereseknek azirányú kérelmüket, hogy a társult perre vonatkozó szabályok szerint kívánnak eljárni, már a keresetlevélben elő kell adniuk, és meg kell jelölniük a társult felpereseket és társulásuk tényét, a (helyettes)reprezentatív felperes személyét, a jogi képviselőnek adott meghatalmazást, a reprezentatív jogot, a reprezentatív tényeket, annak az eszköznek, módszernek a meghatározását, amely alkalmas igazolni, hogy a felperesek mindegyike olyan személy, akinek vonatkozásában a reprezentatív tények fennállnak, és ennek alapján a reprezentatív jog őket megilleti, valamint a társult perlési szerződésre utalást. ${ }^{40}$ Marasztalás iránti keresetben a felperesek követeléseit felperesenként kell megjelölni.

Amennyiben a társult per törvényi feltételei nem állnak fenn, a bíróság az engedélyezés iránti kérelmet elutasítja, egyéb esetekben az engedélyt meg kell adni. E döntést leghamarabb a keresetlevél benyújtásától számított hatvan napon belül lehet, legkésôbb pedig a perfelvételi szak lezárásával egyidejűleg kell határozni. A társult pert engedélyező végzésben rögzíteni kell az elbírálandó reprezentatív jogot, a reprezentatív tényeket és az összekapcsolás igazolásának eszközét, valamint az összekapcsolás tényleges igazolására adott határidőt. Az engedély iránti kérelem elutasítása esetén az eljárást egyidejűleg meg kell szüntetni. A keresetlevél beadásának jogi hatályai fennmaradnak azoknak a felpereseknek a vonatkozásában, akik a végzés jogerőre emelkedésétől számított harminc nap alatt a keresetlevelüket akár egyénileg, akár a társult per szabályai szerint szabályszerūen benyújtják, vagy követelésüket egyéb úton szabályszerűen érvényesítik. ${ }^{41}$

A társult perben a felpereseket megillető jogokat kizárólagosan a reprezentatív felperes gyakorolhatja. A reprezentatív felperes e jogainak szerződéssel való bármely korlátozása a reprezentatív felperes nyilatkozatainak, perbeli cselekményeinek érvényességét és hatályosságát nem érinti. A felpereseket megillető perbeli jogok egységesek és csak egységesen gyakorolhatók.42

A perben eljárni nem jogosult felperesek akaratát pedig a társult perlési szerződés testesíti meg. E szerződés megkötése befolyásolja mind a peres eljárás lefolytatásának módját, mind a perbeli jogok és kötelezettségek gyakorlásának mikéntjét, továbbá tartalmában eljárási típusú rendelkezéseket tartalmaz abban az értelemben, hogy az eljárási jogoknak és kötelezettségeknek a reprezentatív felperes általi gyakorlása hátterét, felhatalmazás-rendszerét teremti meg. Minderre tekintettel nem rendszeridegen és indokolt e szerződési szabályok törvényben történő elhelyezése. ${ }^{43}$ A törvény írásbeliséghez köti a szerződés létrejöttét és felsorolja azokat a kérdésköröket, melyeket okvetlenül szabályozniuk kell a feleknek ahhoz, hogy a társulás múködőképes és méltányos legyen. ${ }^{44}$

\footnotetext{
${ }^{40}$ Pp. 584. \(1) bek.

41 Pp. 585. S.

42 Pp. 589. \.

43 Indoklás a 2016. évi CXXX. törvény 586. \-hoz.

${ }^{44}$ Pp. 586. \ [A társult perlési szerződés].

(1) A társult per megindítása előtt az igényüket ebben a formában érvényesíteni kívánó jogosultaknak írásban társult perlési szerződést kell kötniük. A társult perlési szerződésnek tartalmaznia kell
} 
A társult perbe új felperesként belépni, illetve a társult perből kilépni csak a perfelvételi szakban lehet, és csak a bíróság engedélyével. A bíróságtól az esetleges perbelépések és kilépések engedélyezését a reprezentatív felperes egy alkalommal, összesítetten kérheti. ${ }^{45} \mathrm{Az}$ utólagos belépésre célszerű lehetőséget adni, mivel előfordulhat, hogy a csoport szervezése még nem zárul le a keresetlevél benyújtása előtt. Ugyanakkor a csoport tagjainak kiléte, jogosultságaik sajátosságai befolyásolják a reprezentatív jogok és tények meghatározását, amely a perelőkészítés első lépése, ezért azt nem lehet időkorlát nélkül lehetôvé tenni.

\footnotetext{
a) a társult per felpereseit (e $\int$-ban a továbbiakban: felek),

b) a reprezentatív felperes kijelölését,

c) a reprezentatív felperes helyettesének kijelölését,

d) a társult per vitelére meghatalmazott jogi képviselōt,

e) a társult perlési szerződés megkötésével és a társult per előkészítésével kapcsolatos költségek, továbbá a társult per perköltsége előlegezésének, viselésének, megosztásának szabályait,

f) a feleknek a peranyag szolgáltatással kapcsolatos kötelezettségeit,

g) a reprezentatív felperes felelősségére vonatkozó szabályokat, különösen a szakszerûtlen pervitelből következő károkért való helytállás módját, eszközét,
}

h) annak szabályait, hogy a társult per megindítása után új felek csatlakozhatnak-e a társult perlési szerződéshez, illetve a szerződő felek felmondhatják-e egyedileg a társult perlési szerződést,

i) az egyezségkötés kifejezett tilalmát vagy az egyezségkötésre való kifejezett felhatalmazást azzal, hogy egyezségkötésre felhatalmazás esetén meg kell jelölni azt a minimum összeget és egyéb feltételt, amelynek az egyezségben szerepelnie kell; a felek azt is kiköthetik, hogy az egyezségkötéshez az egyezségtervezet megküldésével hozzájárulásukat kell kérni,

j) az arra vonatkozó kikötést, hogy a reprezentatív felperes meghatározott perbeli nyilatkozatainak, perbeli cselekményeinek megtételéhez a felek előzetes jóváhagyása szükséges-e, k) annak szabályait, hogy a reprezentatív felperes milyen módon tájékoztatja perviteléről a feleket, és hogyan biztosítja a felek tájékozódási lehetőségét, valamint a pervitel ellenőrzését, l) azt, hogy a társult perben a felperesek számára megítélt, illetve jóváhagyott egyezség alapján a felpereseket megillető pénzösszeg, egyéb dolog vagy jog a felpereseket eredeti követelésük arányában illeti meg,

m) a társult perben hozott itélet anyagi jogerőhatásáról szóló tájékoztatást, a lefedett jog és tényalap konkretizálásával,

n) a társult perlési szerződés megszűnésének eseteit, feltételeit.

(2) A felek az (1) bekezdés l) pontjában foglaltakkal ellentétes felosztási tervben nem egyezhetnek meg.

(3) Ha a társult perlési szerződés az (1) bekezdésben előírtakat nem tartalmazza vagy a szerződés tartalmában ellentétes valamely kötelezően alkalmazandó kikötéssel, a bíróság a keresetlevelet visszautasítja. A visszautasítás előtt hiánypótlásra felhívásnak nincs helye. E végzés ellen külön fellebbezésnek van helye. A keresetlevél beadásának jogi hatályai fennmaradnak azoknak a felpereseknek a vonatkozásában, akik a végzés jogerőre emelkedésétől számított harminc nap alatt a keresetlevelüket akár egyénileg, akár a társult per szabályai szerint benyújtják vagy követelésüket egyéb úton szabályszerűen érvényesítik.

(4) A bíróságnak nem feladata ellenőrizni, hogy a reprezentatív felperes a társult perlési szerződésnek megfelelően jár-e el a perben.

45 Pp. 587. S. 
Ez semmilyen szempontból nem sérti a társult per lehetséges felpereseinek rendelkezési jogát, mivel egyéni perindítási joguk mindenkor fennmarad, a határidő elmulasztásával mindössze attól a kedvezménytől esnek el, hogy társult formában érvényesítsék igényüket. Értelemszerūen a belépéshez és kilépéshez szükséges az is, hogy a társult perlési szerződéshez az új felperesek csatlakozzanak, illetve a kilépők azt felmondják. A csatlakozások és kiválások a szerződés eredeti rendelkezéseit - a személyi résztől eltekintve - nem érintik. A perbelépésről és kilépésrôl külön végzést hozni nem kell. Megjegyzendő, hogy a kilépést és a belépést nem kötelező lehetővé tenni a társult perlési szerződésben. ${ }^{46}$

A bíróság a társult perben a felperesek keresetéről egységesen dönt, határozatát a reprezentatív jog tekintetében, a reprezentatív tények vonatkozásában megállapított tényállás alapján hozza meg. A bíróság az ítéletében azoknak a felpereseknek a javára marasztalja alperest, akik vonatkozásban az összekapcsolás tényleges igazolása az előírt határidőben megtörtént. A perköltség tekintetében a reprezentatív felperest kell kötelezni, illetve jogosítani. ${ }^{47}$

Mind a közérdekű, mind a társult per szabályai között megtalálható az a rendelkezés, hogy amennyiben azt az ügy különös bonyolultsága indokolja, ezekben a perekben három hivatásos bíróból álló tanács is eljárhat. ${ }^{48} \mathrm{~A}$ társult per esetén ez azonban csak akkor igaz, ha a per a törvényszék hatáskörébe tartozik. ${ }^{49}$

Említést kell tennünk róla, hogy a szakértői javaslat másképpen képzelte el a kollektív igényérvényesítés rendszerét. A javaslat értelmében a kollektív igényérvényesítés fejezetébe három eljárás került volna. Az actio popularis, mely az 1952. évi III. törvény szabályait lényegében változatlan formában helyezte volna a fejezetbe. A második a társult perlés, melyet a kollektív igényérvényesítés alaptípusának tekintett a javaslat, mely egy opt-in modell keretében a tárgyi hatály korlátozása nélkül, de alapvetően olyan esetekre modellezett eljárás, ahol meghatározott személyek meghatározott (kár)igénye kerül egy eljárásban érvényesítésre. Az ügyek jogalap tekintetében mindenképpen összekapcsolhatók, az összegszerűség kérdésében viszont lehet, hogy individuális perekként fognak folytatódni. És végül az osztályos perlés, mely opt-out modellként csak egy szűk anyagi jogi területen lenne alkalmazható, csökkentve ezzel a visszaélések lehetőségét. Szükséges lenne hozzá a közös tény- és jogalap, valamint előírható lenne egy minimális létszám. Az osztályt a végrehajtásig egységként kellene kezelni, az alperes az osztálynak egy összeget fizetne, melyet a civil szervezet vagy a csoport reprezentatív tagja felosztási terv alapján osztana szét. ${ }^{50}$

\footnotetext{
46 Indoklás 587-589. \-hoz.

47 Pp. 590. \$.

${ }^{48}$ Pp. 573. \ (1) bek. és 282. \ (1) bek.

${ }^{49}$ Pp. 582. \ (1) bek.

${ }^{50}$ Ld. bővebben Harsági 2015, 232-236.
} 


\section{A közérdekü per alkalmazási lehetőségei a környezeti károkkal kapcsolatban}

Sári János úgy fogalmaz, hogy a környezetvédelem sajátossága abban áll, hogy alanya az emberiség és a természet lehetne. ${ }^{51}$

A környezet védelmének általános szabályairól szóló 1995. évi LIII. törvény (a továbbiakban: Kvt.) szerint a környezetterhelés valamely anyag vagy energia közvetlen vagy közvetett kibocsátása a környezetbe. ${ }^{52}$ A környezetvédelmi egyesületek a jelenleg hatályos szabályok szerint is pert indíthatnak a környezethasználó ellen a környezet veszélyeztetése, szennyezése vagy károsítása esetén, kérve a bíróságtól, hogy a jogsértőt tiltsa el a jogsértő magatartástól, vagy kötelezze a kár megelőzéséhez szükséges intézkedések megtételére. ${ }^{53}$ Továbbá környezeti veszélyeztetés esetén az ügyész is jogosult keresetet indítani a tevékenységtől való eltiltás, illetôleg a környezetveszélyeztető tevékenységgel okozott kár megtérítése iránt. ${ }^{54}$ Ez 2018. január 1. után is így marad, így közérdekű pereket a Kvt. alapján a környezetvédelmi egyesület és az ügyész egyaránt indíthat. A környezet veszélyeztetése esetén az ügyész is jogosult keresetet indítani a tevékenységtől való eltiltás, illetőleg a környezetet veszélyeztető tevékenységgel okozott kár megtérítése iránt. A Kvt. az ügyész keresetindítási jogát szűkebb körben vonja meg a Kvt. 101. 』-ában meghatározott, a jogsértő tevékenység alapján alkalmazható jogkövetkezmények körénél. Eszerint a jogsértő tevékenység folytatója az e törvényben és a külön jogszabályokban meghatározott felelősséggel tartozik. Köteles a környezetveszélyeztetést, illetőleg környezetkárosítást abbahagyni, a tevékenységével okozott kárért helytállni, a tevékenységet megelőző környezeti állapotot helyreállítani. A (3) bekezdés szerint az a) pontban meghatározott magatartás elmaradása vagy eredménytelensége esetén a bíróság a jogsértő magatartást tanúsító személy tevékenységét korlátozhatja, felfüggesztheti, megtilthatja. Az idézett jogszabályi rendelkezések egybevetéséből az következik, hogy az ügyész által a környezetet veszélyeztető tevékenységtől való eltiltás iránt indított kereset megalapozottsága esetén a bíróság a Kvt. 101. \ (3) bekezdésében meghatározott tartalmú döntést hozhatja, tehát megtilthatja a környezetet veszélyeztető tevékenység folytatását. A jogintézmény analóg a Ptk. 341. \ (1) bekezdésében (jelenleg 6:523. \) meghatározott rendelkezéssel, amely kivételesen a még be nem következett, de reálisan fenyegető potenciális károkozás esetén a jogszabályban meghatározott szankció alkalmazását teszi lehetővé, amennyiben tehát a kár bekövetkezése a jövőben várható, annak megelőzését a bíróság ítéletével kikényszerítheti. A jogszabály rendelkezéséből következik, hogy amennyiben a kárveszély elhárult, a jogviszony természetéből következően a veszélyeztető magatartástól eltiltás szankciója jogalapját veszíti. Jogalap hiányában pedig a(z 1952. évi) Pp. 123. \ második mondata szerint a kárveszély korábbi fennállásának megállapítására irányuló kereseti kérelmek, illetve ilyen megállapítást tartalmazó ítélet hozatalának sincs helye.

\footnotetext{
${ }^{51}$ Sári János - Somody Bernadette: Alapjogok, Alkotmánytan II, Osiris, Budapest, 2008, 179.

${ }^{5}$ Kvt. 4. \$ 6. pont.

${ }^{53}$ Kvt. 98-99. S, Gyimesi Tamás Ferenc: A res iudicata a kollektív igényérvényesítés tekintetében, Iustum Aequum Salutare, 2015/2, 180.

${ }^{54}$ Kvt. 109. S.
} 
Eltérően ítélendő meg az ügyész megállapítási keresetindítási jogosultsága, ha a környezetet veszélyeztető tevékenységgel okozott kár megtérítése iránt indít keresetet. A hivatkozott jogesetben helytállóan hivatkozott a felperes arra, hogy az ügyész marasztalásra irányuló keresetindítási joga kiterjed az ugyanazon jogviszonyból eredő megállapítási keresetindításra is, amennyiben a Pp. 123. \-ában meghatározott további együttes jogszabályi feltételek is fennállnak. Ez esetben is feltételt képez, hogy a kárigénynek a jövőre nézve a károkozó és a keresetindításra jogosult ügyész jogviszonyában jogalapjában már fenn kell állnia. ${ }^{55}$ A hivatkozott ügyben azonban az ügyész nem kártérítés, hanem a veszélyeztető tevékenységtől eltiltás iránt indította meg a keresetét, így a Legfelsőbb bíróság a jogerős elutasító ítéletet helybenhagyta. A természetes személyeket e körben nem illeti meg a keresetindítási jog, ezt a Legfelsőbb Bíróság ítéletében is kifejtette. ${ }^{56}$

A társult perekkel kapcsolatban az Országgyúléshez beterjesztett javaslat csak az első két ügytípust tartalmazta, és a parlamenti vita során egészült ki a környezetvédelmi tárgyú ügyekkel, az Alapvető Jogok Biztosának a Jövő Nemzedékek Érdekeinek Védelmét Ellátó Biztoshelyettese kezdeményezésére. Indokai a következők voltak: a költséghatékonyság ezekben a perekben is kimutatható, mivel ugyan meg van a lehetőség az egyéni perindításra, azonban a költségek egyenlőtlen elosztása miatt sokszor nem indul egyéni per. Csak olyan pert lehet e körbe bevonni, ahol az alapul fekvő anyagi jogi igények jellegzetességéből fakadó módon tipikus az, hogy megvannak a közös jogi és ténybeli alapok és ezek indokolják a perek összekapcsolásának lehetővé tételét. Az e körben érvényesíthető igények köre meglehetősen korlátozott: visszavezethetőnek kell lennie egy olyan környezetterhelésre, mely egészségkárosodást vagy vagyoni kárt okoz a felperesi csoport tagjainak, és ez a károsultak számára nem volt előre látható, azaz a rendes üzemi múködés körén kívül esnek, és emberi tevékenység vagy mulasztás következményei. ${ }^{57} \mathrm{Az}$ előre nem láthatóság követelményének beépítésével csak a katasztrófaszerű, váratlan, jogellenes környezetterhelő események érvényesíthetőek társult perben.

A Pp. azonban tudatosan nem a környezetterhelés fogalmához köti a társult perlési jogosultságot, hanem környezetterhelésből adódó károsodáshoz. A kár illetve a sérelemdíj mértéke egyénenként eltérő lehet, ami indokol némi egyéniesítést, pl. az egészségkárosodás mértékének megállapítása szakértői vizsgálattal. Minderre azonban már csak a felelősségi jogalap megállapítását követően kerülhet sor, és ennek során is felhasználható a jogalap bizonyítása körében felhasznált bizonyítékok köre. Ráadásul a felelősség megállapítása után a felek számára nyitva álló egyezségkötés lehetősége is előtérbe kerül. A környezethasználó a Kvt-ben meghatározott és más jogszabályokban szabályozott módon büntetőjogi, polgári jogi és közigazgatási jogi felelősséggel tartozik tevékenységének a környezetre gyakorolt hatásaiért.

${ }^{55} \mathrm{EBH} 2000.321$.

${ }^{56}$ BH 2007. 259., és EBH 2006. 1418.

57 Wallacher 2017. 
A Kvt. szerint a környezet igénybevételével, illetőleg terhelésével járó tevékenységgel vagy mulasztással másnak okozott kár környezetveszélyeztető tevékenységgel okozott kárnak minősül, és arra a Ptk. fokozott veszéllyel járó tevékenységére vonatkozó szabályait kell alkalmazni. A környezet igénybevételével okozott kár megtérítése nem érvényesíthető a társult perben, mivel e fogalom rendkívül tág lenne. ${ }^{58}$

\section{5. Összegzés}

Zárásképpen, ezzel is rámutatva a téma jelentőségére, az uniós vonatkozásokról szeretnénk ejteni egy pár gondolatot. Ahogyan arra a bevezetésben is utaltunk, az egészséges környezethez való jog alapjognak tekintendő, így nem meglepő, hogy védelmét nemzetközi egyezmények és az Európai unió is biztosítja. Témánk szempontjából azonban kiemelendő az Aarhus Egyezmény, ${ }^{59}$ melynek egyik kulcskérdése az igazságszolgáltatáshoz való hozzáférés széleskörű biztosítása a nyilvánosság számára környezeti ügyekben. Azonban mivel a környezetben bekövetkezett károk sajátossága, hogy míg az egyéni károk összege alacsony, a perindítás kockázata és költsége pedig magas, így az Egyezmény, melyhez az Európai Közösségek 2005-ben csatlakozott, elsősorban nem az egyének jogait, hanem a közérdeket védi. Az igazságszolgáltatáshoz való jog széleskörű biztosítása éppen emiatt főként a nemzeti jogszabályok által erre feljogosított szervezetek perindítása révén valósulhat meg a leghatékonyabban, még akkor is, ha jogerős döntés peres úton, kollektív formában való megtámadása nem az egyének érdekeit, hanem a közérdekét szolgálja. ${ }^{60}$ Ezen kívül számos jogrendszerben, például a magyarban is, az ügyészt illeti meg hasonló perindítási jogosultság. Itt is érdemes lehet kihangsúlyozni, hogy e perek megindításával kapcsolatban azért nem a magánszemélyek kerültek nevesítésre, mert ők a kockázatot és a várható nyereséget mérlegelve valószínúleg nem tudnák hatékony módon érvényesíteni az érdekeiket ilyen jogvitákban. Ebből a megközelítésből alapvetően a közérdekű perre vonatkozó szabályokat érezhetjük alkalmazandónak, de véleményem szerint a társult perek is megfelelhetnek az Egyezményben foglaltaknak, amennyiben a felperesi társaságot tekinthetjük jogszabály által feljogosított 'szervezetnek' vagy még egyszerübben ha a környezetvédelmi egyesületet jelöljük meg reprezentatív felperesként.

Láthatjuk tehát, hogy az új Polgári perrendtartás kollektív igényérvényesítéssel kapcsolatos szabályai, a Kvt-ben adott felhatalmazással együtt európai mértékben is alkalmasak a környezetben okozott károk peres úton történő érvényesítésére.

\footnotetext{
${ }^{58}$ Kvt. 103. S.

59 A környezeti ügyekben az információhoz való hozzáférésről, a nyilvánosságnak a döntéshozatalban történő részvételéről és az igazságszolgáltatáshoz való jog biztosításáról szóló, Aarhusban, 1998. június 25-én elfogadott Egyezmény.

${ }^{60}$ Mariolina 2014, 257-266.
} 